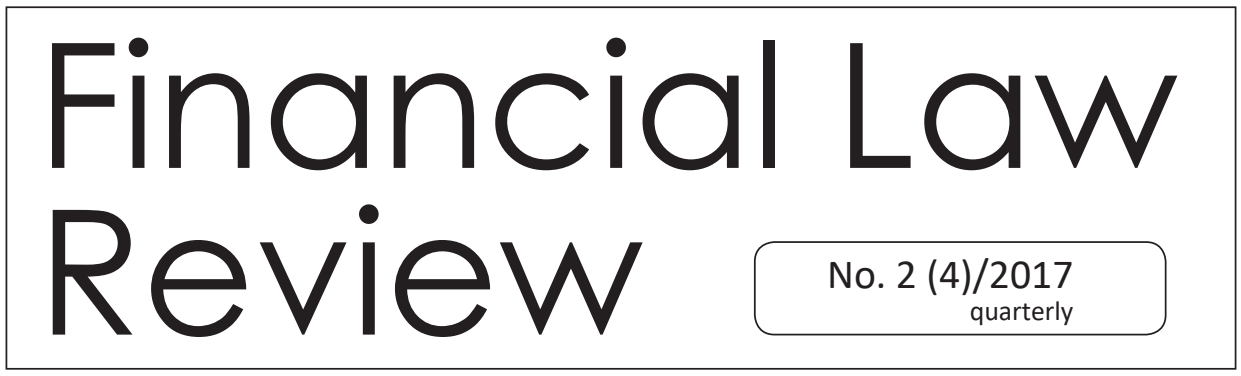

UNIVERSITY OF GDAŃSK • FACULTY OF LAW AND ADMINISTRATION

http://www.ejournals.eu • http://czasopisma.bg.ug.edu.pl

\title{
LEGAL REGULATION OF PUBLIC EXPENDITURES IN THE RUSSIAN FEDERATION $^{1}$
}

Alexey G. Paul*

Budget expenditures are an important component of any budget. A budget as a financial plan consists of budget expenditures, budget revenues and sources of budget deficit financing.

Modern budget legislation of the Russian Federation considers budget expenditures as a sum of money, which is paid from budget on non-repayable conditions. Earlier we included budget credit (repayable disbursement) in budget expenditures. But now budget credit formally refers to sources of budget deficit financing. Sources of budget deficit financing are a part of a budget where we reflect repayable receipts and repayable disbursement. This change in budget legislation reflects on features of legal regulation of budget expenditures.

\footnotetext{
${ }_{1}$ The article is a reprint of the article originally published in Prawo finansowe samorządu terytorialnego: Prawo finansowe wobec wyzwan XXI wieku. Local finance law: The financial law towards challenges of the XXI century J. Gliniecka (red.), CeDeWu, Warszawa 2013

* $\mathrm{PhD}$, a lecturer of financial law department, Voronezh State University, Russia
} 
1. Budget expenditures are a concept used in Russian budget law. However grounds of budget expenditure origins belong to other branches of law. Budget expenditures are based on so-called expenditure obligations. At the same time expenditure obligations are determined by civil law, law of social maintenance, etc. And the main purpose of the budget law is to create a legal mechanism of realization of the expenditure obligations.

In the Russian Federation there are three levels of power: federal, regional and local. Each level has its own competence. The competence is determined by the Constitution of the Russian Federation and some federal laws ${ }^{2}$. On the ground of the competence each level of power adopts laws, other statutory acts, makes contracts and agreements. And the laws, other statutory acts, contracts and agreements include expenditure obligations of appropriative level of power. So expenditures obligations are distributed among levels of power on a base of competence distribution.

Every level of power makes a list of expenditures obligations. And the list is a schedule for expenditure part of appropriative annual budget. According to Russian Budget Code budget bill is made with a view of financial maintenance of expenditure obligations (art. 169).

A law on budget contains budgetary appropriations that are considered to be a limit amount of money resources provided for the implementation of expenditure obligations in a financial year. If budgetary appropriations are sufficient for implementation of all kinds of expenditure obligations we do not have any problems with execution of the budget. However in the event that budgetary appropriations are not sufficient for implementation of expenditure obligations execution of a budget gets a great problem.

In the beginning of budget reforms (in earlier $2000^{\text {th }}$ ) that problem was solved with a reducing of expenditure obligation financing or even cancelling of expenditure obligations. In the first edition of Russian Budget Code federal legislator tried to give a priority in regulation of budget expenditure financing to a law on budget. There was a norm according to which if in the law on budget there were no enough money for expenditure obligation financing the law on the budget was

\footnotetext{
2 The Federal law of 06.10.1999 N 184-FZ "On General principles of organization of legislative (representative) and executive bodies of state power of the subjects of the Russian Federation" // http://www.consultant.ru (translated from Russian); The Federal law of 06.10.2003 N 131-FZ "On General principles of organization of local self-government in the Russian Federation" http://www. consultant.ru (translated from Russian).
} 
applied. It meant that such expenditure obligations were not financed. Moreover Russian Budget Code gave to law on budget a possibility to suspend operation of laws contained expenditure obligations in case of absence of budget resources (budgetary appropriations) for their financing (art. 83 in first edition). However judiciary practice did not support that rules. The Supreme Court of the Russian Federation decided that absence of resources in budget couldn't be the reason for refusal in financing of expenditure obligations. The Russian Constitutional Court accepted some acts about suspend of social expenditure obligations. The Court specified that such suspension undermined trust of citizens to legislation and authorities actions ${ }^{3}$. Besides according to Constitutional Court acts law on budget anyway should not suspend an operation of other laws that create expenditure obligations ${ }^{4}$. As a result, now the legislator does not try to refuse financing of any expenditure obligations provided by the legislation.

So, problem of financing of expenditure obligations was solved. At least now we have exact legal position about financing of expenditure obligations. Budgetary appropriations for financing of all expenditure obligations should be included in the law on budget. If budgetary appropriations are not sufficient for financing of all expenditure obligations creditor (recipient) has an opportunity to take a legal action. And a court recovers appropriative sum of money on the base of laws, other statutory acts, contracts and agreements providing for expenditure obligations. In such case absence of money in budget (absence of budgetary appropriations in a law on budget) does not have significance for the court decision.

2. Last years the main direction of Russian budget law reforms concerned budget expenditures was a transition to programme budgeting and an increase of budgeting horizon ${ }^{5}$.

2.1. Earlier budgets of all levels of power in the Russian Federation were mainly formed by indexing of previous year budget expenditures. We use line-item budgeting. There were no estimations of budget expenditure resulting effects. Budget management represented control of expenditure compliance with law on budget.

\footnotetext{
3 Act of the Russian Constitutional Court of 04.12.2003, N 415-O // http://www.consultant.ru (translated from Russian).

${ }^{4}$ Act of the Russian Constitutional Court on 23.04.2004, N 9-P // http://www.consultant.ru (translated from Russian).

${ }^{5}$ Conception of the Russian Federation budget process reform in 2004 - 2006. Adopted by the Decision of the Russian Federation Government on 22.05.2004. № 249 // www.consultant.ru (translated from Russian).
} 
Later the Government of the Russian Federation decided to introduce programme budgeting conception of budget expenditure planning. In such case a budget is formed on the basis of planned state policy results. Budget appropriations are directly connected to state functions (services, activities) and during expenditure planning much attention is paid to expected results of expenditures.

This reform is based on a widely spread model of "budgeting oriented towards results within the framework of the middle-termed finance planning". Its essence lies in the distribution of the budget resources in accordance with real results (supplied services) and taking into consideration medium-terms priorities of the social-economic policy.

Firstly we should define priorities in state or local policy and establish expected results. After that it is necessary to work out measures to achieve the results. Then it is possible to calculate a cost of the measures. And the cost of measures is a basis for budget expenditures for realization of the appropriative expected results. As a result we get performance budget.

Various purpose programs play significant role in budget expenditure planning. A new edition of Russian Budget Code provides long-term purpose programs, departmental special purpose programs and a federal targeted investment program. The programs contain expected results, measures to achieve the results and a cost of the measures.

So, now Russian budget law started to use a programme budgeting as a methodology of budget expenditure planning.

2.2. One of basic element of the budget reforms taken place in the majority of the developed countries last decades was a transition to middle-term (long-term) budgeting. According to this concept a budget cycle begins with consideration of middle-term (long-term) financial plan parameters adopted in the previous budget cycle, with analysis of changes in external factors and conditions, and with a substantiation of the changes in the basic budget indicators of planning year.

From 2007 Russian Budget Code provides budgeting not for one year but for three years (for next fiscal year and a two-year planned period). So, widely known in the international practice method of "sliding three-year budgeting" was realized in Russian Budget Code. In such conditions earlier adopted budget expenditures for second and third years of the three-year period become the basis of the next year budget. 
On the one hand "sliding three-year budgeting" provides stability and predictability of budget expenditures. On the other hand authorities have possibility to react to changes, to re-structure of expenditure obligations and to realize of new priorities of a budget policy.

The principle of middle-term (long-term) budgeting is used by the majority of developed countries: the Great Britain, Canada, the Netherlands, Sweden, Denmark, Finland, Norway, France, Australia and New Zealand.

The mentioned directions of budget expenditure reforms have been formulated and have started at federal level. However today federal authority tries to spread this experience to subjects of the Russian Federation and to local governments. Now Russian Ministry of finance works out Program of budget expenditure efficiency increase till $2012^{6}$. One of the tasks of the Program is implementation of programme middle-term (long-term) budgeting to regional and local budget process.

3. Modern Russian budget legislation defines a mechanism of execution of a budget including expenditure financing. Russian Budget Code prescribes for all levels of power a principle of treasury-based budget execution. It means that government bodies (recipients of budget resources) could not establish a budget account in a bank. They have a right to establish a personal account in a Federal Treasury only. And the Federal Treasury could establish a budget account in a bank (in the Central Bank of the Russian Federation). Such mechanism lets to prevent misapplication of budget resources. Furthermore the treasury-based budget execution lets to realize a principle of single budget account. It means that each level of power has one budget account only. And this account is used for reception of revenues and implementation of expenditures. As a result budget resources concentrate on one account. It helps to administer appropriative budget.

It is interesting that regional and local authorities do not have a right to establish regional or local budget accounts in a bank as well. The Russian Budget Code demands regional and local authorities to establish personal accounts of their budgets in the Federal Treasury. And the Federal Treasury could establish regional and local budget accounts in the Central Bank of the Russian Federation (art. 215.1). Some subjects of the Russian Federation tried to contest that competence of the Federal Treasury in the Constitutional Court of the Russian Federation. However the Constitutional Court decided that the article does not contradict

\footnotetext{
${ }^{6}$ http://www.minfin.ru (translated from Russian).
} 
the Constitution of the Russian Federation, since the norm contained in it implies that the Federal Treasury does not entitled to dispose of regional budget resources, to define the directions of their spending, and to sanction the payment from the account of the regional budget. On the opinion of the Constitutional Court cash execution of the regional budget is carried out by the Federal Treasury in order to centralize information about public finances as a whole in the Russian Federation. The constitutional base of the norm is the constitutional power of the Russian Federation on financial regulation, which provides the most efficient functioning of the budgetary system and the optimum organization of interbudgetary relations (art. 71 of the Constitution of the Russian Federation).

So mechanism of regional and local budget execution resembles the following. If regional or local government bodies (recipients of budget resources) want to make a payment they send necessary documents in appropriative regional or local financial authority where they have their personal accounts. The financial authority should check the documents, purpose of proposed expenditures and then it sanctions the payment. After that the financial authority sends the documents to the Federal Treasury. And the Federal Treasury charges off budget resources from the account of the regional or local budget for the payment.

Thus it is obvious that the Russian Federation defines basis in legal regulation of budget expenditures. The federal level of power determines the guidelines for budget expenditure reforms. And federal bodies have significant powers to execute not only federal budget, but also regional and local budget as well.

\footnotetext{
Abstract

Budget expenditures are a sum of money, which is paid from budget on non-repayable conditions. They are based on expenditure obligations that are determined by different branches of law. Budget law should secure so that budgetary appropriations for financing of all expenditure obligations should be included in law on budget.

Budget expenditure planning transferred from line-item budgeting to programme budgeting. Budget Code provides budgeting for next fiscal year and a two-year planned period. All levels of power should follow a principle of treasury-based budget execution and a principle of single budget account. Regional and local authorities should establish personal accounts of their budgets in the Federal Treasury that establish regional and local budget accounts in the Central Bank.
} 